\title{
Isolation and Chemical Analysis of the Sheaths of the Filamentous Cyanobacteria Calothrix parietina and $C$. scopulorum
}

\author{
By JÜRGEN WECKESSER, ${ }^{1 *}$ KARIN HOFMANN, ${ }^{1}$ UWE J. JÜRGENS, ${ }^{1}$ \\ BRIAN A. WHITTON ${ }^{2}$ AND BERND RAFFELSBERGER ${ }^{3}$ \\ ${ }^{1}$ Institut für Biologie II, Mikrobiologie, der Albert-Ludwigs-Universität, Schänzlestr. I, \\ D-7800 Freiburg i. Br., Federal Republic of Germany \\ ${ }^{2}$ Department of Botany, University of Durham, Durham DHI 3LE, UK \\ ${ }^{3}$ Gödecke AG, Berlin, Mooswald-Allee 1-9, D-7800 Freiburg i. Br., Federal Republic of Germany
}

(Received 17 July 1987; revised 4 December 1987)

\begin{abstract}
The sheaths of two species of cyanobacteria, Calothrix parietina (two strains) and C. scopulorum (one strain), were studied. Their fine structure showed osmiophilic fibres running parallel to the cell surface. Enriched sheath fractions were obtained from both species in high yields in the phenol/water interphase after hot phenol/water extraction of cell homogenates. The purified sheaths of the two species had similar chemical compositions, with about $50 \%$ (of sheath dry weight) neutral sugars (galactose, glucose, mannose, xylose, arabinose, rhamnose, fucose, a 2-Omethylhexose and an unidentified 2-O-methyl sugar), $5 \%$ amino acids and small amounts of glucosamine and galacturonic acid. The sheath composition was independent of changes in the iron or phosphate content of the culture medium. The sheath was insoluble in water, and its chemical composition remained essentially unchanged on application of drastic extraction methods, including boiling in $2 \%(\mathrm{w} / \mathrm{v})$ SDS. The sheath bound heavy metals (up to at least $0.7 \%$ of sheath dry weight) with the effectiveness (measured as absolute quantities) $\mathrm{Fe}>\mathrm{Zn}>\mathrm{Cu}>\mathrm{Ni}>\mathrm{Mn}>\mathrm{Mo}>\mathrm{Co}$. Ni, $\mathrm{Cu}, \mathrm{Zn}$ and $\mathrm{Fe}$ were highly enriched relative to their concentration in the culture medium. The concentration factors for $\mathrm{Mo}, \mathrm{Mn}, \mathrm{Ca}, \mathrm{Na}$ and $\mathrm{K}$ were low.
\end{abstract}

\section{INTRODUCTION}

Calothrix, which belongs to Section IV of cyanobacteria according to the classification of Rippka et al. (1979), has a complex developmental cycle, with hormogonia being formed from the ends of trichomes (Livingstone \& Whitton, 1983). The unbranched trichomes are up to $1 \mathrm{~mm}$ long, typically tapering from base to apex, and are surrounded by a thick sheath. Hormogonia are formed by apical release of about ten cells which lack both a sheath and cyanophycin, and are enriched in gas vacuoles and polyphosphate granules. Absence of combined nitrogen leads to the formation of basally located heterocysts (Rai et al., 1978), a thicker sheath and sometimes loss of tapering. 'Hairs' (long, thin, vacuolated, colourless cells at the end of the trichome) or false branches may be formed during starvation of phosphate, iron or (rarely) magnesium (Sinclair \& Whitton, 1977; Livingstone \& Whitton, 1983; Douglas et al., 1986).

The chemical composition of the sheaths of the cyanobacteria Chroococcus minutus (Adhikary et al., 1986), Gloeothece (Weckesser et al., 1987) and Chlorogloeopsis (Schrader et al., 1982a) has been described. Except for the last, which produces filaments under some conditions, none of these are filamentous cyanobacteria. This paper describes a technically easy method for the isolation of the sheath of Calothrix species, and gives a chemical description of the sheath and data on metal binding. 


\section{METHODS}

Organism and growth. Calothrix parietina strains D184 and D550 were from the culture collection of the Department of Botany, University of Durham, UK. C. scopulorum was obtained from the culture collection of the Institut für Pflanzenphysiologie der Universität, Göttingen, FRG.

The cyanobacteria were grown in two different media: medium I (low phosphate and high iron concentration), and medium II (high phosphate and low iron concentration). The media contained (mg l-1): $\mathrm{K}_{2} \mathrm{HPO}_{4} \cdot 3 \mathrm{H}_{2} \mathrm{O}, 7$ (medium I) or 74 (medium II); $\mathrm{CaCl}_{2} .2 \mathrm{H}_{2} \mathrm{O}, 50 ; \mathrm{MgSO}_{4} .7 \mathrm{H}_{2} \mathrm{O}, 200 ; \mathrm{NaCl}, 230 ; \mathrm{KCl}, 19 ; \mathrm{FeCl}_{3} .6 \mathrm{H}_{2} \mathrm{O}, 10$ (medium I) or 2 (medium II). The iron was added as a Fe-EDTA complex, which was prepared by dissolving $\mathrm{Na}_{2}$ EDTA $(12.7 \mathrm{~g})$ in water $(400 \mathrm{ml})$ before the addition of $\mathrm{FeCl}_{3} \cdot 6 \mathrm{H}_{2} \mathrm{O}(9.7 \mathrm{~g})$; the volume was adjusted to 11 and appropriate volumes were employed for media I and II. The final concentrations of trace elements (prepared as a separate stock solution) were $\left(\mathrm{mg} \mathrm{l}^{-1}\right): \mathrm{MnSO}_{4} .2 \mathrm{H}_{2} \mathrm{O}, 0.4 ; \mathrm{Na}_{2} \mathrm{MoO}_{4} \cdot 2 \mathrm{H}_{2} \mathrm{O}, 0.06 ; \mathrm{ZnSO}_{4} .7 \mathrm{H}_{2} \mathrm{O}, 0.05$; $\mathrm{CuSO}_{4} .5 \mathrm{H}_{2} \mathrm{O}, 0.02 ; \mathrm{H}_{3} \mathrm{BO}_{3}, 0.7 ; \mathrm{CoCl}_{2} .6 \mathrm{H}_{2} \mathrm{O}, 0.01 ; \mathrm{NiSO}_{4} .6 \mathrm{H}_{2} \mathrm{O}, 0.01$. HEPES $\left(0.4 \mathrm{~g} \mathrm{I}^{-1}\right)$ was added to the medium and the $\mathrm{pH}$ adjusted to 7.6 with $1 \mathrm{M}-\mathrm{NaOH} . \mathrm{K}_{2} \mathrm{HPO}_{4}\left(740 \mathrm{mg} \mathrm{l}^{-1}\right)$ was autoclaved separately and added after cooling.

Cultures $(300 \mathrm{ml})$ were grown in 11 Erlenmeyer flasks illuminated with cool white fluorescent light $(1500 \mathrm{~lx})$, with shaking, at $25^{\circ} \mathrm{C}$ for 3 weeks. The cyanobacteria were harvested by filtration through a filter paper, washed with distilled water and lyophilized.

Isolation of the sheath. Lyophilized cells $(300 \mathrm{mg}$ ) were suspended in $40 \mathrm{ml} 20 \mathrm{mM}$-Tris/ $\mathrm{HCl}$ buffer, $\mathrm{pH} 8.0$, and broken by passing twice through a French pressure cell at $83 \mathrm{MPa}$. The homogenate was treated with hen eggwhite lysozyme (EC 3.2 .1 .17 ) ( $5 \mathrm{mg}$ in $25 \mathrm{ml} 20 \mathrm{~mm}$-ammonium acetate buffer, pH $6.8,37^{\circ} \mathrm{C}, 12 \mathrm{~h}$ ) and then washed three times with water $(50 \mathrm{ml})$ by centrifugation at $20000 \mathrm{~g}, 22^{\circ} \mathrm{C}, 30 \mathrm{~min}$, removing the upper sheath layer each time by pipette. The sheath (in $20 \mathrm{ml}$ water) was further purified by addition, dropwise, into $20 \mathrm{ml}$ boiling $2 \%(\mathrm{w} / \mathrm{v}) \mathrm{SDS}$. After boiling for $15 \mathrm{~min}$, cooling to $22^{\circ} \mathrm{C}$ and centrifugation $\left(10000 \mathrm{~g}, 22^{\circ} \mathrm{C}, 30 \mathrm{~min}\right)$, the sediment was washed about seven times with $20 \mathrm{ml}$ water before lyophilization.

Hot phenol/water extraction of the cell homogenate was performed by the method of Westphal et al. (1952). After cooling to about $10^{\circ} \mathrm{C}$ and phase-separation by centrifugation $\left(5000 \mathrm{~g}, 10{ }^{\circ} \mathrm{C}, 30 \mathrm{~min}\right)$, the phenol/water interphase was taken with a Pasteur pipette and dialysed extensively against running tap water and finally against distilled water.

Analytical chemical methods. Conditions for liberation of neutral and amino sugars, uronic acids, amino acids and fatty acids were as described by Schrader et al. $(1982 b)$. Neutral sugars were quantified by gas-liquid chromatography as alditol acetates, reduced with $\mathrm{NaBD}_{4}$ for mass spectrometric fragmentation. The alditol acetates were separated on an ECNSS-M glass column ( $2 \mathrm{~mm} \times 1.5 \mathrm{~m}, 3 \%$ on Gas-Chrom Q, 100-200 mesh) using a Varian Aerograph, model 1400-1. Injection and column temperatures were both $240{ }^{\circ} \mathrm{C}$. Mass spectrometric analysis of the sugar alditol acetates was performed on a Finnigan MAT GC/MS automatic system, model 1020. Mass spectra were taken at $70 \mathrm{eV}$ in the mass range $m / e$ 43-400 in $1 \mathrm{~s}$. Fatty acids were estimated by gas-liquid chromatography as methyl esters using an EGSS-X column, $15 \%$ on Gas-Chrom P, 100-200 mesh. Amino sugars and amino acids were separated on an automatic amino acid analyser (Evers et al., 1986). Uronic acids were separated by high-voltage paper electrophoresis (Kickhöfen \& Warth, 1968) and determined quantitatively by the carbazole method (Galambos, 1967). Phosphorus was determined by the method of Lowry et al. (1954).

For metal determination, $10-12 \mathrm{mg}$ sheath (dry weight) was dissolved in $0.5 \mathrm{ml}$ concentrated $\mathrm{HCl}$ containing $10 \mu \mathrm{lF}$ by heating to $160^{\circ} \mathrm{C}$ for $2 \mathrm{~h}$ in an autoclave $(5 \mathrm{MPa})$. Stock solutions of the corresponding metals were treated similarly. Samples were then diluted with de-ionized water to the appropriate volumes. Measurements of $\mathrm{Cu}, \mathrm{Co}, \mathrm{Ni}$ and $\mathrm{Mo}$ were made with a Perkin-Elmer 2380 atomic absorption spectrophotometer with hollow cathode lamps, together with a Perkin-Elmer HGA 76 graphite furnace and a deuterium background corrector. For determination of $\mathrm{Zn}, \mathrm{Fe}, \mathrm{Mn}, \mathrm{Ca}, \mathrm{K}$ and $\mathrm{Na}$, a Perkin-Elmer 3030B flame atomic absorption spectrophotometer with hollow cathode lamps (air/acetylene or acetylene/dinitrogen monoxide flames) was used.

Electron microscopy. Freshly harvested cells were fixed in $1 \%(\mathrm{w} / \mathrm{v})$ osmium tetroxide, dehydrated in alcohol and polymerized in Epon using standard procedures. Ultrathin sections were stained with uranyl acetate followed by lead citrate (Golecki, 1977). A Philips EM 400 microscope was used at $80 \mathrm{kV}$.

\section{RESULTS}

\section{Sheath of C. parietina strains D184 and D550}

In ultrathin sections, the sheath of $C$. parietina D550 showed an osmiophilic fine structure with the fibres running parallel to the cell surface (Fig. 1). The fibres were more densely packed in the outer area of the sheath. A large space between sheath and cell wall (presumably caused by shrinkage during embedding for electron microscopy) indicated that the sheath is not bound to the cell wall (Fig. 1). 


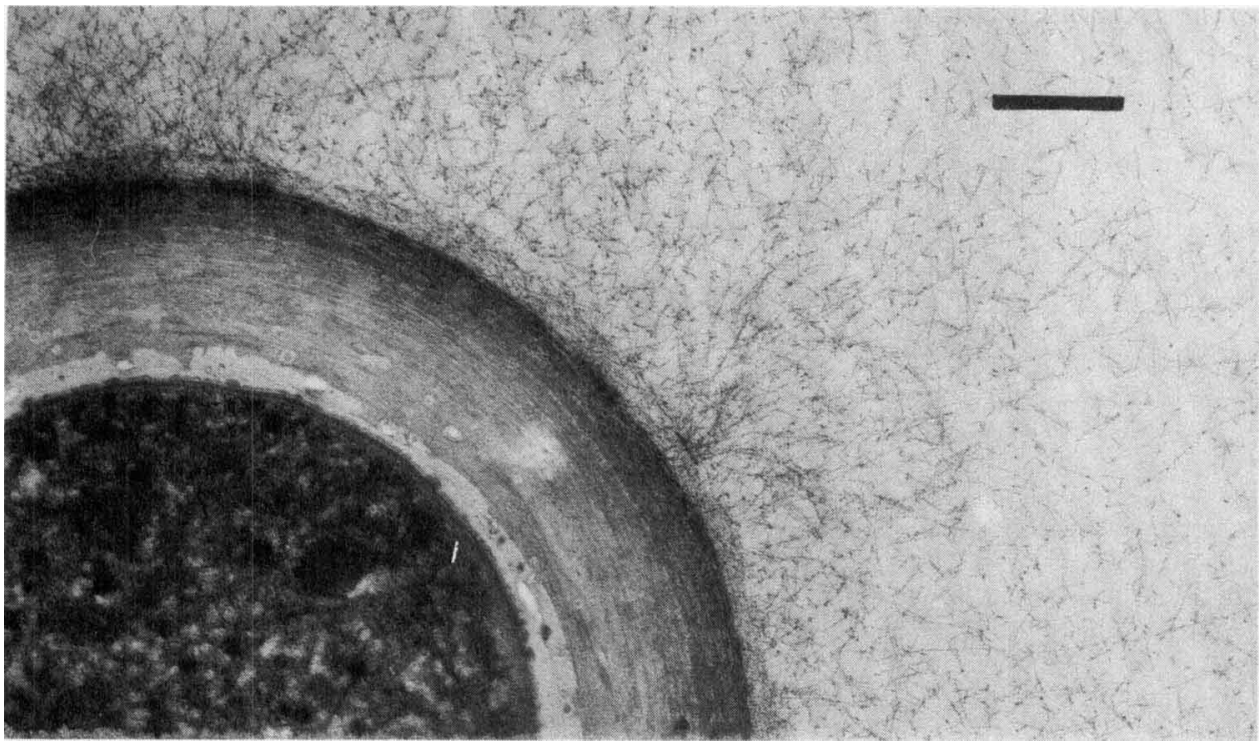

Fig. 1. Ultrathin section of $C$. parietina D550 grown in medium I. Note the relatively thick peptidoglycan layer in the cell wall. Bar, $0.5 \mu \mathrm{m}$.

\section{Table 1. Chemical composition of sheath fractions of C. parietina D184 grown in medium I} (low phosphate, high iron)

Each value is the mean of two determinations. + , Present, but not quantified.

\begin{tabular}{|c|c|c|c|c|c|}
\hline \multirow[b]{2}{*}{ Constituent } & \multicolumn{5}{|c|}{ Content ( $\%$ of fraction dry weight) after treatment with: } \\
\hline & Lysozyme & $\begin{array}{c}\text { Lysozyme } \\
+ \text { SDS }\end{array}$ & $\begin{array}{c}\text { Phenol/ } \\
\text { water }\end{array}$ & $\begin{array}{c}\text { Phenol/ } \\
\text { water } \\
+ \text { lysozyme }\end{array}$ & $\begin{array}{c}\text { Phenol } \\
\text { water } \\
+ \text { lysozyme } \\
+ \text { SDS }\end{array}$ \\
\hline Rhamnose & $1 \cdot 2$ & $1 \cdot 2$ & $1 \cdot 3$ & $1 \cdot 3$ & $1 \cdot 3$ \\
\hline Fucose & $1 \cdot 4$ & $0 \cdot 3$ & 1.0 & 1.0 & 0.9 \\
\hline Arabinose & 2.5 & $2 \cdot 2$ & 2.9 & 2.7 & 2.7 \\
\hline Xylose & 3.0 & $2 \cdot 5$ & $3 \cdot 4$ & $3 \cdot 1$ & $3 \cdot 1$ \\
\hline 2-O-Me-hexose & 1.6 & 0.9 & $2 \cdot 2$ & $2 \cdot 1$ & 1.9 \\
\hline 2-O-Me-sugar & + & + & + & + & + \\
\hline Mannose & $4 \cdot 8$ & $5 \cdot 1$ & $5 \cdot 7$ & 5.9 & $5 \cdot 1$ \\
\hline Galactose & $9 \cdot 4$ & $9 \cdot 5$ & $12 \cdot 9$ & $11 \cdot 1$ & $10 \cdot 2$ \\
\hline Glucose & $12 \cdot 7$ & 14.9 & $17 \cdot 0$ & $16 \cdot 2$ & 16.0 \\
\hline Fatty acids & $0 \cdot 1$ & 0.2 & 0.1 & 0.2 & $0 \cdot 2$ \\
\hline Galacturonic acid & $3 \cdot 3$ & 3.0 & $3 \cdot 8$ & $1 \cdot 2$ & $3 \cdot 0$ \\
\hline Phosphorus & 0.04 & 0.01 & 0.03 & 0.03 & 0.02 \\
\hline Glucosamine & $1 \cdot 3$ & 0.8 & $1 \cdot 1$ & 0.9 & $1 \cdot 1$ \\
\hline Muramic acid & + & + & + & + & + \\
\hline Diaminopimelic acid & + & + & + & + & + \\
\hline Amino acids (total) & $17 \cdot 2$ & $9 \cdot 0$ & 15.6 & $17 \cdot 6$ & $14 \cdot 4$ \\
\hline
\end{tabular}

Sheaths from $C$. parietina D184 and D550 were obtained from cell homogenates by lysozyme treatment, followed by differential centrifugation. Further purification was achieved by treatment with $2 \%(\mathrm{w} / \mathrm{v})$ boiling SDS. The yield was $20-30 \%$ of cell dry weight with both strains. The neutral sugar content was about half of the sheath material dry weight, with galactose and glucose dominating over mannose, xylose, arabinose, rhamnose, fucose and two $O$-methyl sugars (data obtained with strain D184: Table 1). The $O$-methyl sugar having a retention time of 
Table 2. Metals in the isolated sheath (obtained from cell homogenates by boiling $2 \%, w / v, S D S$ treatment, $15 \mathrm{~min}$ ) from $C$. parietina D550, grown in media with different iron and phosphate contents

Values shown are the mean of three determinations.

\begin{tabular}{|c|c|c|c|}
\hline \multirow[b]{3}{*}{ Metal } & \multicolumn{3}{|c|}{ Concentration in } \\
\hline & \multirow{2}{*}{$\begin{array}{l}\text { Culture medium } \\
\qquad\left(\mu \mathrm{g}^{-1}\right)\end{array}$} & \multicolumn{2}{|c|}{$\begin{array}{c}\text { Sheath fraction } \\
{\left[\mu \mathrm{g}(50 \mathrm{mg} \text { lyophilized sheath })^{-1}\right]^{*}}\end{array}$} \\
\hline & & Medium I $\dagger$ & Medium II $\dagger$ \\
\hline $\mathrm{Fe}$ (medium I) & 420 & 304 & \\
\hline $\mathrm{Fe}$ (medium II) & 84 & & 125 \\
\hline $\mathrm{Mn}$ & 130 & 3 & 4 \\
\hline Mo & 26 & 2 & 2 \\
\hline $\mathrm{Zn}$ & 12 & 17 & 8 \\
\hline $\mathrm{Cu}$ & 5 & 12 & 7 \\
\hline $\mathrm{Ni}$ & 2 & 9 & 7 \\
\hline $\mathrm{Co}$ & 2 & 2 & $0 \cdot 2$ \\
\hline $\mathrm{Ca}$ & 14000 & 347 & 420 \\
\hline $\mathrm{K}$ & 10000 & 103 & $<25$ \\
\hline $\mathrm{Na}$ & 92000 & 207 & $<25$ \\
\hline
\end{tabular}

* $50 \mathrm{mg}$ lyophilized sheath corresponds roughly to the amount isolated from 11 of culture.

$\dagger$ Medium I, low phosphate, high iron; medium II, high phosphate, low iron (see Methods for details).

0.48 (relative to inositol, as alditol acetate derivatives) on gas-liquid chromatography showed primary fragments at $m / e 333$ and 118 and secondary fragments at $m / e 259,171$ and 139 , indicating it to be a 2-O-methylhexose (Jansson et al., 1976). The other $O$-methyl sugar (relative retention time 0.53 ) was present in only small amounts. Among other fragments, it showed one of $m / e 118$, characteristic of a 2-O-methyl sugar. It was not further characterized. In addition to some galacturonic acid, small amounts of glucosamine, muramic acid and diaminopimelic acid were found. The latter three compounds were probably due to contamination by peptidoglycan. The fatty acid and phosphorus contents were very low (Table 1). About $10 \%$ of the amino acid residues could not be removed by the detergent treatment. Essentially comparable data were obtained with the sheath of strain D550 (data not shown). The absolute amount of metals in the sheath was determined for strain D550 (Table 2). Heavy metals were bound up to above $0.7 \%$ of sheath dry weight with the effectiveness (measured as absolute quantities) $\mathrm{Fe}>\mathrm{Zn}>\mathrm{Cu}>$ $\mathrm{Ni}>\mathrm{Mn}>\mathrm{Mo}>\mathrm{Co}$. A high enrichment of $\mathrm{Ni}, \mathrm{Cu}, \mathrm{Zn}$ and $\mathrm{Fe}$, relative to their respective concentrations in the culture medium, was observed, while $\mathrm{Mn}, \mathrm{Ca}, \mathrm{Mo}, \mathrm{K}$ and $\mathrm{Na}$ were only slightly enriched.

A similar sheath composition was obtained when a different isolation procedure was applied, in which the cell homogenate was treated with hot phenol/water (Table 1). With both strains, the sheath was found entirely in the phenol/water interphase (yield $25 \%$ of cell dry weight). Further purification by lysozyme treatment and a subsequent SDS treatment (as above) did not change the composition (Table 1). Accordingly, an additional hot phenol/water treatment of the sheath fraction, obtained by SDS extraction, again extracted the sheath into the phenol/water interphase. The chemical composition remained unchanged (examined with strain D550; data not shown).

There were no significant differences in yield and chemical composition of the sheath fractions isolated from cells grown in media with different phosphate and iron contents (medium I or medium II).

Several attempts were made with the sheath of $C$. parietina D550 to cleave off the polysaccharide moiety from the protein portion. They included treatment of the sheath at $60^{\circ} \mathrm{C}$ in $0.5 \mathrm{M}-\mathrm{NaOH}$ for $12 \mathrm{~h}$ or in $2 \mathrm{M}-\mathrm{NaOH}$ for $48 \mathrm{~h}$. In both cases some material was not solubilized, and no clear-cut separation of the polysaccharide from the protein moiety was achieved upon centrifugation $\left(48000 \mathrm{~g}, 4^{\circ} \mathrm{C}, 20 \mathrm{~min}\right)$. The sheath could not be dissolved in 
Schweitzer reagent. However, after treatment with $\mathrm{HF}\left(48 \%, \mathrm{v} / \mathrm{v}, 0{ }^{\circ} \mathrm{C}, 48 \mathrm{~h}\right)$ and centrifugation $\left(176000 \mathrm{~g}, 4^{\circ} \mathrm{C}, 60 \mathrm{~min}\right)$ about $70 \%$ of the sheath dry weight was obtained in the supernatant. The latter was highly enriched in neutral sugars, while the sediment contained nearly all of the amino acids (data not shown).

\section{Sheath of C. scopulorum}

C. scopulorum had a somewhat thinner sheath layer than the two C.parietina strains, as judged by light microscopy. The yield of isolated sheath in the phenol/water interphase of hot phenol/water extracts of cell homogenates was $20 \%$ of the cell dry weight. The chemical composition and metal-binding capacity of the $C$. scopulorum sheath were essentially identical to that of the two $C$. parietina strains (data not shown).

\section{DISCUSSION}

The hot phenol/water procedure proved to be a suitable method for the isolation of the sheath of the two Calothrix species. It is technically easy and gave highly enriched sheath fractions in good yields in the phenol/water interphase with all three strains examined. The partition into this phase is caused by the high insolubility of the Calothrix sheath, and thus this method may also be applicable to the insoluble sheath fractions from other cyanobacteria such as Chlorogloeopsis (Schrader et al., 1982a). In contrast, the more soluble sheath of the unicellular Gloeothece sp. was extracted into the water phase by a comparable extraction method (Weckesser et al., 1987). There may be a correlation between insolubility and the staining density of the osmiophilic fine structure: both were high with Calothrix spp. and Chlorogloeopsis sp., whereas the sheaths of Gloeothece sp. have a less osmiophilic fine structure (Weckesser et al., 1987).

The chemical composition of the sheath remained essentially unchanged on application of the various drastic extraction conditions such as hot phenol/water or boiling SDS treatment. This might indicate high purity of the sheath fraction, but it might also be explained by the presence of insoluble material other than sheath. The sheath fraction certainly contains peptidoglycan, as indicated by the presence of muramic and diaminopimelic acids. Thus, the possibility cannot be excluded that some of the sugars found are part of a peptidoglycan-polysaccharide complex, as in the unicellular Synechocystis sp. PCC 6714 (Jürgens \& Weckesser, 1986). However, such a contribution would be small, because of the low relative content (about $0.1 \%$ ) of peptidoglycanspecific compounds in the fraction. With Chlorogloeopsis sp. PCC 6912 a polysaccharide different from that of the sheath was found and suggested to be a cell wall constituent (Schrader et $a l ., 1982 b$ ). No comparable polysaccharide was detected in the water phase of the phenol/water extracts of cell homogenates of the Calothrix strains.

Like the sheaths of other cyanobacteria (Drews \& Weckesser, 1982; Adhikary et al., 1986; Weckesser et al., 1987), the complex sugar spectrum with pentoses, hexoses, and $O$-methyl sugars indicates high specificity of the sheath in Calothrix spp. $O$-Methyl sugars are characteristic constituents of cell wall polysaccharides from phototrophic prokaryotes (Drews \& Weckesser, 1982; Weckesser et al., 1979). The sugars are not due to contamination by lipopolysaccharide, since $\beta$-hydroxy fatty acids, which are characteristic constituents of lipopolysaccharides of Gram-negative bacteria and cyanobacteria (Weckesser et al., 1979), were lacking in all the sheath fractions isolated in this study. Interestingly, a protein content of at least $5 \%$ (of sheath dry weight) was not removed by any of the drastic extraction conditions applied. A possible binding between polysaccharide and protein would be worthy of study.

Only about $60 \%$ of the sheath fraction dry weight was identified. This may be due to the observed partial insolubility of the sheath under the hydrolytic conditions used and by a possible degradation of identified compounds during hydrolysis. Insolubility, together with mechanical stability and resistance to enzymic treatment, will render sheath layers from cyanobacteria relatively stable against destruction in their natural environment. Thus, the sheaths of cyanobacteria can play a major part in sedimenting detritus material in lakes and in geological sediments (Aizenshat et al., 1984; Krumbein, 1983).

The sheaths of both Calothrix spp. bound heavy metals, which were enriched in the order 
$\mathrm{Ni}>\mathrm{Cu}>\mathrm{Zn}>\mathrm{Fe}>\mathrm{Co}>\mathrm{Mo}$, relative to their concentrations in the medium. However, as is clear from the data presented in Table 2, some contribution has to be ascribed to additional, contaminating metals (in non-defined amounts) collected by the sheath during cell cultivation and the isolation of the sheath. This holds true certainly at least for the excess of $\mathrm{Fe}, \mathrm{Cu}, \mathrm{Ni}$ and $\mathrm{Zn}$ determined in the sheath relative to their concentration in the culture medium. The concentration factor for $\mathrm{Mn}$, needed in photosystem $\mathrm{II}$, was low. $\mathrm{Ca}, \mathrm{K}$ and $\mathrm{Na}$ also showed low enrichment factors. A comparable concentration of metals has been described for the sheath of Microcystis from a natural habitat (Amemiya \& Nakayama, 1984), except that a higher relative concentration factor for $\mathrm{Mn}$ was measured in that study and the relative $\mathrm{Ca}, \mathrm{K}$ and $\mathrm{Na}$ content of the sheath of the Calothrix spp. was much lower than described for that of Microcystis. The sheath of Calothrix spp. seems to bind only heavy metals, which in excess amounts are toxic to the cell, and it might therefore have a protective function.

The authors thank J. R. Golecki for electron micrographs. The work was supported by the Deutsche Forschungsgemeinschaft.

\section{REFERENCES}

ADHIKARY, S. P., WeCKesser, J., JÜrgens, U. J., GoleCKI, J. R. \& BOROWIAK, D. (1986). Isolation and chemical characterization of the sheath from the cyanobacterium Chroococcus minutus SAG B.41.79. Journal of General Microbiology 132, 2595-2599.

Aizenshat, Z., LiPINER, G. \& CoHEN, Y. (1984). Biogeochemistry of carbon and sulfur cycle in the microbial mats of the Solar Lake (Sinai). In Microbial Mats; Stromatolites, pp. 281-312. Edited by Y. Cohen, R. W. Castenholz \& H. O. Halvorson. New York: Alan R. Liss.

AmEmiYa, Y. \& NakaYama, O. (1984). The chemical composition and metal adsorption capacity of the sheath materials isolated from Microcystis, cyanobacteria. Japanese Journal of Limnology 45, 187-193.

Douglas, D., Peat, A. \& Whitton, B. A. (1986). Influence of iron status on structure of the cyanobacterium (blue-green alga) Calothrix parietina. Cytobios 47, 190-191.

DRews, G. \& WeCKesser, J. (1982). Function, structure and composition of cell walls and external layers. In The Biology of Cyanobacteria, pp. 333-357. Edited by N. G. Carr \& B. A. Whitton. Oxford: Blackwell Scientific Publications.

Evers, D., WeCKesSER, J. \& JüRGENS, U. J. (1986). Chemical analyses on cell envelope polymers of the halophilic, phototrophic Rhodospirillum salexigens. Archives of Microbiology 145, 254-258.

Galambos, J. T. (1967). The reaction of carbazole with carbohydrates. Analytical Biochemistry 19, 119-132.

GolECKI, J. R. (1977). Studies on ultrastructure and composition of cell walls of the cyanobacterium Anacystis nidulans. Archives of Microbiology 114, 3541.

JANSSON, P. E., KenNe, L., LiedGren, H., LindBerg, B. \& LöNNGREN, J. (1976). A practical guide to the methylation analysis of carbohydrates. Chemical Communications 1976, no. 8, 1-74.

Jürgens, U. J. \& WeCkesser, J. (1986). Polysaccharide covalently linked to the peptidoglycan of the cyanobacterium Synechocystis sp. strain PCC 6714. Journal of Bacteriology 168, 568-573.

KICKHÖFEN, B. \& WARTH, R. (1968). Eine Trennkam- mer für die Hochspannungselektrophorese nach dem Michel'schen Prinzip. Journal of Chromatography 33, 558-560.

KRUMBEIN, W. E. (1983). Microbial Geochemistry. Oxford: Blackwell Scientific Publications.

Livingstone, D. \& WhitTon, B. A. (1983). Influence of phosphorus on morphology of Calothrix parietina (Cyanophyta) in culture. British Phycological Journal 18, 29-38.

LOWRY, O. H., ROBERTS, N. R., LEINER, K. Y., WU, M. L. \& FARR, A. L. (1954). The quantitative histochemistry of brain. I. Chemical methods. Journal of Biological Chemistry 207, 1-17.

Rai, A. K., Pandey, K. D. \& Kashyap, A. K. (1978). Heterocyst differentiation and polarity in Calothrix. New Phytologist 81, 647-651.

RiPPKa, R., Deruelles, J., Waterbury, J. B., Herdman, M. \& Stanier, R. Y. (1979). Generic assignments, strain histories and properties of pure cultures of cyanobacteria. Journal of General Microbiology 111, 1-61.

Schrader, M., Drews, G., Golecki, J. R. \& WECKESSER, J. (1982a). Isolation and characterization of sheath from the unicellular cyanobacterium Chlorogloeopsis PCC 6912. Journal of General Microbiology 128, 267-272.

SCHRADER, M., DREWS, G., WECKESSER, J. \& MAYER, H, $(1982 b)$. Polysaccharide containing 6-O-methylD-mannose in Chlorogloeopsis PCC 6912. Journal of General Microbiology 128, 273-277.

Sinclair, C. \& WhitTon, B. A. (1977). Influence of nitrogen source on morphology of Rivulariaceae (Cyanophyta). Journal of Phycology 13, 335-340.

WeCkesser, J., Drews, G. \& MAYer, H. (1979). Lipopolysaccharides of photosynthetic prokaryotes. Annual Review of Microbiology 33, 215-239.

WeCKesser, J., Broll, C., ADHIKARY, S. P. \& JÜRGENS, U. J. (1987). 2-O-Methyl-D-xylose containing sheath in the cyanobacterium Gloeothece sp. PCC 6501. Archives of Microbiology 147, 300-303.

WeSTPHAL, O., LÜDERITZ, O. \& BISTER, F. (1952). Über die Extraktion von Bakterien mit Phenol/Wasser. Zeitschrift für Naturforschung 7b, 148-155. 